\title{
Comparative Study of International Commercial Arbitration and International Law in Iran
}

\author{
Soheila Hashemi ${ }^{1} \&$ Nader Mardani ${ }^{2}$ \\ ${ }^{1}$ UAE Branch, Islamic Azad University, Dubai, UAE \\ ${ }^{2}$ Departments of Law and Political Science, Shiraz University, Shiraz, Iran \\ Correspondence: Soheila Hashemi, UAE Branch, Islamic Azad University, Dubai, UAE. E-mail: \\ soheila.hashemi88@gmail.com
}

Received: May 15, 2016 Accepted: June 15, 2016 Online Published: August 30, 2016

doi:10.5539/jpl.v9n7p242 URL: http://dx.doi.org/10.5539/jpl.v9n7p242

\begin{abstract}
Arbitration is one of the most important solutions to end enmity and replace judicial inquest. As international trading is extended, referring to judgment to solve the conflicts caused by commercial contracts has been rapidly rising which is a result of judgment benefits over justice authorities. Fastness and efficiency, law inquest cost, compromise nature of selecting the referees, and professional selection are among the most evident specifications of arbitration. Furthermore, Iran's involvement in the most significant judgment case of the last century i.e. the lawsuits filed between the Islamic Republic of Iran the United States of America after the victory of the revolution would double the essentiality of knowing this organization. Judgment may be either individual or organic (permanent) and also the number of referees needs to be one or three. The most important issue in the judge's inquest is to follow two factors including independence and impartiality from the beginning until the end of the inquest process. Violating these characteristics or the lack of one of both or other descriptions predicted in the arbitration contract would result in its violation by one side of the conflict or both of them. In the present paper, a comparison is conducted between the commonalty and distinction of Iran's international commercial arbitration in 1376 and international law.
\end{abstract}

Keywords: referee; the arbitration of international trading; Ad hoc Arbitration; Institutional Arbitration; Tarmes of refrence; jury; mutual agreement; independence; impartiality; international law

\section{Introduction}

International commercial arbitration is a common and useful approach in resolving disputes between international traders, the business with two or more persons are linked. We can say this method of dispute resolution an alternative to domestic courts and for the sake of impartiality and efficiency of the major and significant feature is that court proceedings in most countries do not enjoy. Consolidation of the two third party to resolve their dispute their sentence. This act of the ruling wields two people one-third says consolidation. In jurisprudence consolidate or strengthen legal judgment as judgment raised referee or judge to consolidate the non-appointed judge is called. They are similar in purpose.

As the recourse to arbitration in domestic trade relations to the use of arbitration in contracts of limited recourse to justice, the international commercial contracts with a foreign element is very attractive. The arbitration as the only means of resolving disputes between the parties is not mentioned.

not in vain, in addition to the International Chamber of Commerce, who attempted to formulate a set under the title of regulations and compromise Arbitration Tribunal judge International Chamber of Commerce, especially the various governments and international organizations arising from the womb them several conventions in the last century, to the establishment of the legal matter . international trade disputes between states and foreign private individuals, one of the most important issues that are traditionally and discussed many talks. on the one hand, according to their governments tend to rule the country's laws and tribunals on his contract and the ruling arbitration hearing, on the other hand, foreign investors from fear of the influence of governments and changing the rules of the surest way always search possible. Additionally, and trade disputes arising from investments, in particular, a special kind of disputes and characteristics have their own features and thus settling such disputes method and the rules of the appropriate demanded that most widespread they refer to the judges and a specialist. 


\section{An Explanation of the Necessity of International Commercial Arbitration}

It is necessary to develop the business communities of human progress and science, technology and communications (ground and air) in modern societies, the complexity and diversity of many commercial phenomena that sometimes conflict between businessmen in the two countries to exchange and exporter. Undoubtedly to increase trade interactions nations more trade disputes emerges. So that businessman for exports and imports from developing countries near and far international law on a large scale which is based on mutual behavior These inaccessible action and reaction.

It means that exporting country and the country's ruling decrees and know each other in their own country. Reciprocity may be caused by law, treaty, and Tribunals or procedure which identify the verdict in a matter of fact the official confirmed that has been valid votes legal works. Rights science along with other science is in the direction of globalization and able to step in various fields such as the literary and artistic property rights, human rights, maritime rights, financial and economic rights, monotonous of laws to create a new international judicial system. In the global village, sovereignty, classical concepts have lost their duty and co - ordination. Implementation of the uniform regulations is governing the most important tasks and racism, racial discrimination, very pale and humans are as citizens of the global village.

Ease international trade relations from a stake in the trade rules and on the other hand resolve trade disputes and legal rules according to the uniform. Lawyers role in different situations like legislation, law and legal adviser speed up the process of uniform rules.

From the moment to implement the decree establishing the referee must be real person must address the referee and the composition and has capacity. The judges through three can be :

1) direct election

2) implicit choice

3) mixed - direct election

A referee Republicans and a referee both sides are chosen. Implicit choice: Both sides agree that anyone else a referee our country and other countries and other referee the next election. Arbitration rules in dealing with no ready unlike the judicial proceedings, and to arbitration substantive and form can be substantial vote review and is not binding but form objectionable and the right to vote there be revised.

International arbitration by a string of private rights sources of national and international sources. Arbitration bodies are divided: 1- litigants 2- reference judgment that if the two no judgment. But foreign arbitration: If litigants and reference of belonging to a country is not foreign arbitration. International arbitration had nothing to do with litigants when judgment is that the international forum in accordance with the laws of any country. The Chamber of Commerce in the name of the ICC duties for the settlement of disputes between businessmens is usually a Justice, not just because of the private sector cannot create justice.

Practical assaults that involve an objection and protest to each of the minimum standards of the attributes of public or private qualities. With such incident it cannot blame the referee in conformity and without prejudice to the verdict which it cannot be a result of such a fair hearing has been achieved.

\section{Iran's International Commercial Arbitration}

In Iran after legislation of international trade in the years that 1997how the international arbitration in Iran and the possibility of holding an international trade in international trade relations, the ambiguity must also tackle that judgment issued votes out of Iran. If it is necessary how can identify and implemented in Iran and vice versa? In fact with the approval of the international commercial arbitration law, a very important step in connection with the spread of international trade between Iran and other steps to Iran in the international scene as a good place to hold international arbitration and among certain countries and international arbitration. It rules and determines how to identify and the implementation of the votes in the judgment issued outside Iran that dealing with Iran. The choice to join the Treaty of 1958in New York on identifying and implementing foreign arbitration votes in the year 2002 did not only allow the identification of foreign arbitration votes and the votes are in Iran. But the judge issued in Iran as well as in other countries who are members of the treaty to be applicable. In Iran since the annexation of the treaty the number of 96 countries to join it. The number of member states of the international treaty until that time. In addition to having a very good reflects the success of the document suggests that the treaty could expectations of such a number of countries.

After reunification Iran, 40 other countries also acceded to such a large number of countries around 4during the last year of belonging to the treaty. From his own opinions, they agreed to arbitration (foreign) and help with the 
identification and implementation of votes. The treaty in fact for the member states of the law constitutes about identifying and implementing foreign arbitration votes which are the legal conditions and easy stipulates. So not only upholds the same rules to identify and implementation of votes in the international arena but also the two.

As a professional approach to resolving trade disputes

institutional judgment is very old but until the middle of the nineteenth century in the relationship between people. Just to settle a dispute with the people who lived or preserving relations among themselves as they were members of a family, the neighbors, and partners. Judgment is closely related to compromise only when the attention and organizing the fact that the dispute and to the judge. when the parties to the man who were known as the referee and was most likely to vote for various reasons to honor him. The decision yet but not from the traditional developed a completely new.

Today often before the judge is expected to create discord and it seems that the aim of the jurisdiction of the court more self - government, not order in which the two sides can work together right. If not friendly relations regulations that legal systems for different kinds of traditional judge imposed often with the judgment of a new kind of matches. business circles, lawyers, legislators, judges and practical work to employment rights inevitably have to consider. Several organizations to apply judgment - created to judge by the regulations of the new rules have been set for the modernization of the old laws approved. When these laws are not reform, claiming the judicial interpretation of the law has evolved. As well as an international treaty, books and articles published a raft of - and - established arbitration special journals. However, it seemed that the spread of academic research - along with comparative study was like Iran and international B - use in this regard. The arbitrator conditions including capacity (wise grown up ). In conformity Due - not favor and a foreign party and minister and member of parliament - that one of the dire need for change and innovation, judgment and another method of new - and resolve the conflict. Change in the current approach - related to meet the needs of the people today are not human - can 't to resolve differences - month and the year - to waste time and wait for the outcome of any size is valuable, don't be valuable time. As a result in different fields of understanding the world prefer that differences in all specialties by experts in the field to be addressed the time and cost less justice and to coordinate with knowledge of the day.

Today professional groups that efficient to settle disputes, Chamber of Commerce in advanced countries in the world and emerging remarkable tendency to push many of these conflicts worldwide arbitration expert authorities. Judgment in each of the three civil rights, eventually faster than the law courts because the arbitration tribunal is only a review of the case, while judicial courts with a lot of cases are expected.

\section{Iran's Role in International Commercial Arbitration}

Iran has a significant role in international trade because usually arbitration on both sides of the International Chamber of Commerce in various citizenship and often don't have any interest in that if there is a conflict appeared in court against his sides and national law which will be dealt with. As well as in all three cases of domestic, foreign (International) according to their position the need to quickly finally keep the secrets of qualified professional is important to prefer contracting parties to the dispute by the referee. Also in accordance with the provisions of the settlement agreement and it is believed that the judgment of justice. So that the two sides and desirable according to the laws that parties consider more convenient for their relations.

Referee freedom in each of the three cases mentioned accepted contract parties in the selection of rights in the nature of the case should be judges are free to carry out there in the condition of the contracts if even one of the two parties would remain in it. It is the quarrel agreement within the jurisdiction of the referee and the court hearing disallowed.

Previously those as the referee would - be trusted by the parties to the dispute the confidence of the parties to guarantee the implementation of the referee vote. Although the conditions have changed on a case - by - side referee or at least one of them - the same principle should be thought capable of individual but without Independence party of intimacy parties or in the past. The rule of international referees most affected by the situation and moral issues such as scientific judgment and the company's international trade. But the referee substantial must be scientific excellence and moral appetite and the need to a referential arbitration body .

Ways mayhem in the international conventions can the principle of citizenship and the lack of objectivity referee specialized him to the rules of the Institute of the mechanisms are expected to be clear that if one or several referees as to be independent and neutral can be mayhem and on the side of the judgment or unqualified.

Assaults mechanism is one of the fundamental guarantees in judgment that of litigants can be supported. On the one hand, the battery makes reference disputes by neutral are resolved and from the other side of the arrival of the 
jury to prevent the judgment. Of course, you may assaults mechanism by the parties are also used to be and to apply pressure on the referees and disrupt the flow of those to be exploited. So it is very important that when a referee mayhem. On arriving at the battery criteria and fixed criteria especially that there is no evidence mayhem usually don't reveal but of that total issued in the mayhem referees criteria for lack of capacity. A lack of special capabilities (misbehavior at the inability of the referee - judge court proceedings) Lack of independence and impartiality of the referee, including cases, can be seen from the referee.

It has been heard that the government passed a resolution to accession to the Convention on the New York 1958 has prepared to give in to the hope is that the approval of the bill. Since it has been accompanied by about efforts to attract foreign investment. It is essential to the ratification of the law of international trade between - without adhering to New York imperative is incomplete. If countries in the fields of trade and attracting international investments and even foreign membership in the World Trade Organization (WTO) should be successful judicial system to its current level and global standards to closer. As mentioned previously the feeling is that the prospects for developing the judge promising in Iran.

At the legislative level has been trying to be updated arbitration rules and a framework for a relatively modern international arbitration trade disputes and at the same time that deficits are trying to reduce the level of awareness of what is now a good judgment role. So that a number of lawyers with relative experience that can create an arbitration regime. They are trying to arbitration bodies such as the Iranian Association of active arbitration and training and familiarity with the aid of jurists and perhaps the judgment. As well as the increasing awareness among the public and private sector business community to arbitration advantages. All they can to help loving judgment that the legal system for the success of a system of arbitration is essential.

\section{Proposals}

Recognizing the vital role of trade and the rights of international trade in the commercial and economic life of nations and with regard to the role of a vital and undeniable rights of international arbitration in the field to build trust between businessmen on other countries to carry out exchanges and trade exchange. The country or traders and country taking into consideration the fact that Iran's rights lack codified rules predicted in this area and resorting to the provisions of miscellaneous interpretative paved the way for the creation of a unified approach. Especially with regard to the fact that the regulations are often in connection with the implementation of the documents and foreign rulings which have complexity and their own crackdown. While their own judgments and implement them to exercise their rights and more have been proposed to identify and implement foreign sentences after about 70 years in Iran's rights laws is designed to carry out of foreign arbitration votes. Also, formulate regulations to create a legal unity in the implementation of foreign arbitration votes in Iran and the foreign trade and international regulations in the shadow of fraud cases against the law and to prevent a proper legal rule over the country's vital.

Well as other this ability to identify and implementation of arbitration votes of Iran in other countries on the basis of reciprocity. Accession to the Convention on the 1958New York and with the rules of the Islamic Republic of Iran's main with regard to the implicit admission protocol lawmaker support and encouragement of investment in the United States and Iran. With regard to its provisions and subject to the inclusion of its member states can step more effective and useful in this regard.

\section{References}

Arzu ongur, E (2011). Rules of International chamber of commerce (ICC). Ankara Bar Review, vol4.

Berhardt, V(1956). Polygraphic company.

BURIAN DES ,R (1959). Ladistincation dudroit civil et du droit commercial et Le droit angl.

Warm,C." International, American Hostages in Iran, the conduct of a crisis", op.cit.

Crook, J, R (1989). Applicable law in International Arbitration: the Iran.us. claims Tribunal Experience "the American Journal of International Law, vol: 83, n': 2.

"Crafting the financial settlement", op, cit.

Dang, k-M (1981). prejudgment Attachment of Frozen Iranian Assets", California Law Review, vol: 69.

“Etatas- unis et Iran(1980). Revue ge'ne'ral de droit International public, Tome 84, vol: 4.

Rouhani, F(1965). International commercial Arbitration, union International des Avocates vol 111 thehague.

Gianviti, F(1980). Leblocage des avoirs officienls Iranians par Les Etats- unis", Revue critigue de droit International prive', vol: $69 . \mathrm{n}: 2$. 
Gordon, E, Lich, L. C (1982). Tvend the decision to block Iranian assets- reexamined"the International Lawyer.

Gordon, E."Trends" the Blocking of International Assets", op. cit.

de vires, H.P(1984). Journal of International vol. 1, No. 1.

Hertz, M. F (1981). The hostage crisis and domestic litigation: an overview "the Iran- united states claims tribunal.

\section{Copyrights}

Copyright for this article is retained by the author(s), with first publication rights granted to the journal.

This is an open-access article distributed under the terms and conditions of the Creative Commons Attribution license (http://creativecommons.org/licenses/by/4.0/). 